\title{
Mateusz Piotrowski
}

Uniwersytet Kardynała Stefana Wyszyńskiego w Warszawie

S. Wojciechowski, P. Osiewicz, Zrozumieć współczesny terroryzm. Wybrane aspekty fenomenu, Difin, Warszawa 2017, ss. 251

$25 / 2018$

Political Dialogues

DOI: http://dx.doi.org/10.12775/DP.2018.018

Książka pt. „Zrozumieć współczesny terroryzm" autorstwa Sebastiana Wojciechowskiego i Przemysława Osiewicza to publikacja, jak się wydaje, bardzo aktualna. Już przeglądajac tematy kolejnych rozdziałów, omawiających głównie problematykę współczesnego terroryzmu, wydaje się, że pozycja powinna zainteresować nie tylko naukowców czy specjalistów, ale także osoby, które „hobbystycznie" interesuja sie lub dopiero chca zaczać swoja "przygodę" $z$ analizą międzynarodowego terroryzmu.

Ksiażka jest podzielona na dwie części, co autorzy wyjaśniaja jeszcze we wstępie - złożonej $z$ siedmiu rozdziałów części pierwszej, poświęconej głównym aspektom terroryzmu oraz złożonej z pięciu rozdziałów części drugiej poruszającej wybrane przejawy terroryzmu. Lektura powinna więc czytelnikom umożliwić poznanie podstaw działania terrorystów, genezy terroryzmu oraz jego skutków i wpływu na społeczeństwo, gospodarkę oraz politykę państw.

Pierwszy rozdział zatytułowany „Podstawowe pojęcia i ich znaczenie" wprowadza czytelnika w tematykę wyjaśniajacc popularność i wykorzystanie słowa „terroryzm”, jego lingwistyczną genezę oraz krótki opis, czym właściwie jest terroryzm, w oparciu o definicje m.in. Or- ganizacji Paktu Północnoatlantyckiego czy RAND Corporation. Dane przedstawione w tekście sa czytelnie uzupełniane przez wykresy, jak np. wykres dotyczacy współczynnika zabójstw w stosunku do liczby ofiar ataków w terrorystycznych. Wojciechowski wyjaśnia ponadto czym różni się terror od terroryzmu i dlaczego warto te pojęcia rozdzielić. Rozdział zamyka przedstawienie modeli funkcjonowania organizacji terrorystycznych, każdy wsparty prostym schematem.

W drugim rozdziale („Geneza terroryzmu") Osiewicz przedstawia genezę terroryzmu funkcjonujaccego jeszcze do $\mathrm{XX}$ wieku oraz wyodrębnia następujace rodzaje terroryzmu: separatysty i kolonialny, terroryzm motywowany religijnie, terroryzm samobójczy. Przedstawia także działania państw, które niekiedy sa podmiotami wspierającymi terroryzm. Rozdział ten wydaje się być skonstruowany w sposób przejrzysty, a uwage przykuwa fakt wyodrębnienia osobnych grup i zwrócenia uwagi na inne rodzaje terroryzmu niż najbardziej aktywny obecnie terroryzm islamski, czyli motywowany religijnie. Pokrótce omówiony został terroryzm państwowy, zwraca się uwagę także na liczne grupy terroryzmu lewicowego i separatystycznego, gdzie szczególną uwagę poświęcono Czerwo- 
nym Brygadom, Frakcji Czerwonej Armii oraz ETA. Dalej Osiewicz przechodzi jednak do genezy terroryzmu najbardziej aktywnego współcześnie, a więc genezy terroryzmu motywowanego religijnie, a dalej, do genezy terroryzmu samobójczego, gdzie m.in. wskazuje na definicję "męczennika za wiarę" pochodząca z Koranu. Kolejną częścią tego rozdziału jest kwestia państw jako podmiotów wspierajacych międzynarodowy terroryzm. Istotne jest także zwrócenie przez autora uwagi na problematykę rozwijającego się zagrożenia w postaci cyberterroryzmu.

„Przyczyny współczesnego terroryzmu" to tytuł III rozdziału autorstwa Wojciechowskiego. W rozdziale tym przedstawione sa główne czynniki generujace i eskalujacce terroryzm, od aspektów terytorialno-etnicznych przez czynniki religijno-kulturowe, uwarunkowania ekonomiczno-społeczne, przyczyny historyczno-polityczne i psychologiczne źródła terroryzmu, aż po procesy migracyjne, rolę mediów w eskalacji terroryzmu i globalizację. Ponadto znajdziemy tu informacje o systematyzacji przyczyn terroryzmu w XX w. oraz autorska koncepcję Wojciechowskiego dotyczaca klasyfikacji źródeł terroryzmu, nazwana przez niego „triada terrorystycznej motywacji”.

Wyróżnia ona trzy grupy przyczyn terroryzmu. Pierwszym sa ideologie o charakterze politycznym, etnicznym lub religijnym. Drugi to uwarunkowania ekonomiczno-społeczne. Trzecim sa aspekty psychiczne. Wojciechowski przekonuje, że terroryzm należy postrzegać nie tylko jako formę propagowania skrajnych i destrukcyjnych idei, lecz także, a może nawet przede wszystkim jako odzwierciedlenie pewnych przekonań czy wierzeń. Ponadto, pewne problemy natury ekonomiczno-społecznej takie jak ubóstwo, analfabetyzm, głód czy ogromne dysproporcje społeczne, także moga wywołać lub potęgować niektóre radykalne postawy. Wreszcie wszelkie postawy negatywne, takie jak strach, wrogość, chęć zemsty, nienawiść czy poczucie zagrożenia ułatwiają manipulacje danymi osobami, co $z$ kolei ułatwia nakłonienie do działań skrajnych. Wszystkie te trzy grupy przyczyn zazębiają się ze sobą wspólnych punktach, wchodząc między sobac w interakcje i tworzac mechanizm triady terrorystycznej motywacji. Choć koncepcja ta w książce nie jest zbyt szeroko omówiona, to w oparciu o wcześniejsze informacje $z$ tego rozdziału wydaje się dopełniać naszą wiedzę o motywach działań terrorystów.

W rozdziale IV Wojciechowski przedstawia kluczowe elementy oraz rodzaje zagrożeń terrorystycznych. Znajdziemy tu więc elementy składowe tworzace szerokie pojęcie terroryzmu, wśród których wyróżniono aż 22 hasła, typologie terroryzmu oraz jego rodzaje, podzielone według pięciu kryteriów - podmiotowego, taktyki i strategii prowadzonej walki, motywów ataku, celu i skutków terroryzmu. Ponadto w rozdziale zawarte sa informacje o różnorodności i złożoności poszczególnych kryteriów motywujących działania terrorystyczne. Definicje zawarte $\mathrm{w}$ tym rozdziale sa zwięzłe, zaledwie kilkuzdaniowe, jednak jest to pewnego rodzaju skrócone kompendium, a $\mathrm{w}$ razie chęci rozszerzenia wiedzy na dany temat przez czytelnika, w książce zawarte sa liczne odesłania do publikacji źródłowych, a także całościowy spis literatury po każdym $z$ rozdziałów.

Rozdział V to już tematyka, która zapewne zainteresuje największą ilość czytelników sięgających po tę publikację, gdyż dotyczy czasów współczesnych, a więc zakresu i charakteru terroryzmu na poczatku XXI wieku. Autorem tego rozdziału ponownie jest Wojciechowski, 
który przybliża skalę zagrożenia terrorystycznego zmieniająca się na przestrzeni ostatnich kilku lat, przedstawia najbardziej aktywne ugrupowania terrorystyczne, metody i motywy działania terrorystów, cele ataków terrorystycznych i wreszcie, następstwa ataków. Rozdział ten, choć niezbyt obszerny, zawiera dane liczbowe i statystyczne, a każdy taki zbiór uzupełniony jest stosowna tabela lub wykresem, co znacznie ułatwia odbiór i porządkuje wiedzę.

W VI rozdziale, który poświęcony jest skutkom terroryzmu, Osiewicz przedstawia kolejno w zakresie wystarczajacym kolejne skutki działań terrorystycznych, które zostały podzielone na pięć grup - skutki polityczne, ekonomiczne, społeczne, militarne oraz psychologiczne. Uwage zwraca odwołanie do danych ekonomicznych oraz pojęć psychologicznych, co czyni ten rozdział wysoce interdyscyplinarnym.

Ostatni rozdział części I, którego autorem jest Wojciechowski, dotyczy zapobiegania i zwalczania terroryzmu, jest więc perfekcyjnym domknięciem wiedzy zebranej w sześciu wcześniejszych rozdziałach. Wojciechowski po krótce omawia czym jest antyterroryzm, kontrterroryzm oraz działania antyterrorystyczne, wskazuje także różnice pomiędzy walka $z$ terroryzmem a wojna $z$ terroryzmem. Wojciechowski zwraca uwage na pewne strategie i modele zwalczania terroryzmu, odnosząc się nie tylko do teorii, ale bazując także na praktycznych modelach wykorzystywanych przez służby niektórych państw, jednocześnie oceniajac skuteczność przedstawionych wcześniej działań, a także przybliża instrumenty, które służą państwu do realizowania polityki antyterrorystycznej.

Część II to konkretne i zarazem bardzo aktualne przykłady terroryzmu. Rozdział VIII, który otwiera tę część książ- ki, poświęcony jest terroryzmowi w Unii Europejskiej. Osiewicz ocenia poziom zagrożenia terroryzmem w państwach Unii na przestrzeni ostatnich lat, przedstawia działania podejmowane przez organy Unii, które miałyby zapobiegać lub walczyć $z$ terroryzmem, zwracając szczególną uwagę na rolę agencji Europol, Eurojust i Frontex. W rozdziale tym znajdziemy także dane $z$ raportów o terroryzmie przygotowanych przez Europol, pokrótce omówioną rolę unijnego koordynatora ds. zwalczania terroryzmu, przedstawienie wybranych aktów prawnych Unii, które maja przeciwdziałać terroryzmowi, a także elementy współpracy Unii jako organizacji $z$ jej międzynarodowymi partnerami. Osoby, które sięgając po te publikację, liczyły na przedstawienie pewnych kazusów, moga się poczuć zawiedzione, jednak jest to książka, która, jak wskazuje sam tytuł, ma pomóc zrozumieć współczesny terroryzm, a nie w kronikarski sposób odtworzyć bieg terrorystycznych wydarzeń w Europie czy na świecie.

Niejako $z$ rozdziału poprzedniego Wojciechowski wyodrębnił rozdział IX, który poświęcony jest terroryzmowi w kontekście problematyki migracji i uchodźstwa, właśnie na przykładzie Unii Europejskiej. Autor przedstawia liczbę wniosków o azyl z wyszczególnieniem państw, których obywatele składali te wnioski i odnosi to do liczby prób i ataków terrorystycznych, które były przeprowadzone w Europie, przedstawiajacc także ich profil ideowy. Choć każdego roku liczba uchodźców przedostajacych się do Europy pozostawała na podobnym poziomie poniżej $1,5 \mathrm{mln}$ uchodźców rocznie (za wyjątkiem 2014 r., kiedy przybyło prawie 4 mln uchodźców), liczba zamachów terrorystycznych (przeprowadzonych $z$ powodzeniem, nieudanych lub udaremnionych) w Europie oscylowała na podobnym poziomie, wahając 
się w zakresie od 152 do 219. Co jednak zwraca uwage to spadek ataków o podłożu separatystycznym. W 2012 r. na 219 zamachów terrorystycznych aż $167 \mathrm{z}$ nich miało podłoże separatystyczne. W 2013 r. separatyzmem nacechowane były 84 ataki ze 152. W roku 2015 tylko 65 ataków z łącznej liczby 211 zostało powiazane $z$ separatystami. Odnotowano jednak pojawienie się ataków inspirowanych religia, których było 17 . Wojciechowski zauważa, że choć fale migracyjne moga być paliwem dla organizacji islamistycznych, gdyż napływ dużej liczby ludności ułatwia rekrutację nowych członków, logistykę czy wreszcie łatwiejsze wprowadzanie do Europy swoich bojowników. $Z$ kolei imigranci spotykaja się nierzadko $z$ niechęcią i stają się celem prześladowań lub ofiarami przestępstw, co także może w łatwy sposób napędzać antyeuropejska machine propagandowa islamskich organizacji terrorystycznych. Wojciechowski wymienia także zagrożenia dla państw. W przypadku Polski wskazuje między innymi zadeklarowanie się Polski w walce przeciwko Państwu Islamskiemu. Co więcej, na koniec rozdziału autor zawarł dane dotyczace liczby zgonów oraz zaginięć imigrantów w ostatnich latach.

Rozdział X omawia zagadnienia najbardziej kojarzone dziś $z$ terroryzmem. Osiewicz przedstawia tu studium przypadku Al-Kaidy wraz $z$ jej wieloletnim przywódca Osama bin Ladenem. Autor przypomina genezę organizacji, rolę ideologii Bractwa Muzułmańskiego, a w szczególności Sajida Kutba. Osiewicz wskazuje też na starcie dwóch podejść ideologicznych wewnatrz struktur Al-Kaidy. Drugie z nich, które miało doprowadzić do utworzenia islamskiego kalifatu, zostało przejęte przez Abu Bakra al-Baghdadiego, obecnego przywódcę Daesh. Omówiona została również rola Ajmana az-Zawahiriego, który po śmierci bin La- dena staną na czele al-Kaidy. $Z$ powodu jego przywództwa wiele osób odłączyło się od tego ugrupowania i przystapiło do Daesh, z którym az-Zawahiri niejako prowadzi ideologiczna wojnę. W rozdziale tym znajdziemy też informacje o strukturze al-Kaidy oraz przykłady jej krwawej działalności, co powinno niejako zaspokoić czytelników rozczarowanych brakiem kazusów w rozdziałach poprzednich.

Wojciechowski dokonuje w kolejnym rozdziale analizy Daesh, a więc tzw. Państwa Islamskiego. Choć autor na samym początku wyjaśnia, iż ten samozwańczy kalifat nie ma podmiotowości prawnomiędzynarodowej, a posiada jedynie elementy państwowości, to niejako przykuwa uwage fakt braku przedrostka „tak zwane", powszechnie wykorzystywanego i podkreślającego brak państwowości Daesh. Wojciechowski omawia genezę powstania Daesh, źródła sukcesów tej organizacji, którymi sa jego zdaniem potencjał militarny oraz logistyczny. Część rozdziału poświęcona jest także międzynarodowej walce $z$ Daesh oraz prognozom, jak rozwinąć moga się formy funkcjonowania tzw. Państwa Islamskiego.

Ostatni rozdział książki, napisany przez Osiewicza, przedstawia koncepcje terroryzmu w kontekście broni masowego rażenia. Pierwsza $z$ nich jest terroryzm CBRN, zaś następnie omówiono koncepcje wykorzystania broni chemicznej, biologicznej, radiologicznej oraz nuklearnej, jako wszystkie elementy składowe tzw. „superterroryzmu". W podsumowaniu rozdziału omówiono działania państw, które maja zapobiec powstaniu superterroryzmu oraz ocenę realnego zagrożenia atakiem bronia CBRN w kontekście raportów Departamentu Obrony USA oraz Europolu.

Podsumowaniem publikacji jest przedstawienie przez autorów kilkunastu uwag końcowych, które zawierają zarów- 
no ich własne spostrzeżenia, jak i wnioski powstałe w oparciu o inne źródła lub funkcjonujace już koncepcje. Publikacja jako całość jest bardzo klarowna, jej objętość nie jest zbyt mała, by uznać ja za niewyczerpująca, a jednocześnie nie powinna odstraszyć żadnego z czytelników $z$ powodu zbyt dużej liczby stron. Rozdziały sa spójne, ich tematyka zdecydowanie ze sobą współgra, a także narracja obydwu autorów nie wydaje się być rozbieżna czy chaotyczna. Jest to więc pozycja zdecydowanie godna polecenia, która $z$ powodzeniem mogłaby służyć jako podręcznik wprowadzający do problematyki współczesnego terroryzmu. 